\title{
INSECTICIDE USE PATTERNS FOR APHIDS AND VIRUS INCIDENCE IN AUTUMN SOWN CEREALS IN CANTERBURY
}

\author{
D.E. JAMES, C.D. FLETCHER and D.A.J. TEULON \\ Crop \& Food Research, Private Bag 4704, Christchurch, New Zealand \\ Corresponding author: jamesd@crop.cri.nz
}

From 1998 to 2003, excluding 2001, patterns of insecticide use and virus incidence were established for between 43 and 69 fields per year of autumn sown wheat in Canterbury. Fields were visually inspected for barley and cereal yellow dwarf virus (YDV) in November and December each year. Growers were surveyed on their use of insecticides to control aphids in these fields between emergence and growth stage 30 (the period when the plant is most susceptible to YDV). The proportion of early sown (before 1 May), mid sown (1-15 May) and late sown (after 15 May) crops remained similar throughout the surveyed period. There was a substantial increase in the use of imidacloprid (a seed treatment) and foliage sprays of synthetic pyrethroids while the use of organophosphates reduced. Between 1998 and 2003, fields in which virus incidence was $>5 \%$ of the visible flag leaves declined from about $25 \%$ to near zero. High virus incidence occurred in some (but not all) crops: in a year with extensive aphid flights (even in crops with protectant insecticide applications); in early sown crops without insecticide protection; and in mid and late sown crops without insecticide protection in years with warm June temperatures.

\section{THE INCURSION OF THE LETTUCE APHID INTO TASMANIA - COULD IT HAVE BLOWN OVER FROM NEW ZEALAND?}

\author{
M.A.W. STUFKENS ${ }^{1}$, S.E. NICHOL ${ }^{2}$, S.R. BULMAN ${ }^{1}$ and G.M. DRAYTON ${ }^{1}$ \\ ${ }^{1}$ Crop \& Food Research, Private Bag 4704, Christchurch, New Zealand \\ ${ }^{2}$ NIWA, Private Bag 14-901, Kilbirnie, Wellington, New Zealand \\ Corresponding author: stufkens@crop.cri.nz
}

Lettuce aphid (Nasonovia ribisnigri) was found on lettuces around Devonport, Tasmania, Australia, on 11 March 2004. DNA fragments approximately 600 bp long from the $N$. ribisnigri cytochrome b and cytochrome oxidase I genes were sequenced. Lettuce aphid collected from New Zealand and Tasmania yielded identical sequences, providing preliminary evidence of a shared origin. Tasmanian back air trajectories (going back in time for 8 days for three end-point altitudes, 100, 300 and $1000 \mathrm{~m}$ above ground level (AGL), for the north-east corner of Tasmania, $40.95^{\circ} \mathrm{S}, 148.02^{\circ} \mathrm{E}$, between 1 December 2003 and 31 March 2004) showed that air flow to Tasmania generally originated from the west. However, between 28 and 31 January 2004, at 100 and $300 \mathrm{~m}$ AGL, air flowed from the South Island of New Zealand (mainly from the southern region) to Tasmania. Despite the numbers of lettuce aphid being low (12.8/trap on average per week) in four suction traps (7.5 m AGL) in Canterbury, New Zealand, during the last week of January, these populations may be the source of the incursion. Thus, lettuce aphid from New Zealand may have been transported in these air currents or have arrived by other means. 